\title{
Oil Rent and Regional Economic Development in MENA
}

\author{
Giacomo Luciani
}

\begin{abstract}
Oil rent has created a regional dynamic in the Middle East and North Africa (MENA) whereby major political developments take place at the regional rather than the single-state level. The Arab Spring was a regional phenomenon, and the entire region is today involved in a regional civil war. The regional dimension of democratic transitions has often been postulated and supported in the literature.

In seeking appropriate economic strategies that may support the democratisation process, the regional dimension cannot be forgotten: purely national recipes have little chance of success. Ever since the heyday of pan-Arabism, economic integration within the Arab region has been a recurring theme and objective, but accomplishments remain profoundly disappointing. This chapter reviews findings and the literature concerning the three dimensions of regional integration - merchandise trade, movements of labour and movements of capital-and details the insufficient progress that has been made.

It is difficult to envisage a significant improvement in the development prospects of individual Arab countries unless greater success is achieved in pursuing regional integration. At the same time, the implementation of a new regional economic order also requires a new political order. The main difficulty in this respect is that those countries in the region that have the most economic assets and tools- the major Gulf exporters - are ruled by patrimonial monarchies rather than political forces, and their model of governance cannot be exported.
\end{abstract}

\section{Introduction}

The existing state order in the Middle East and North Africa (MENA) has frequently been questioned. Early views, which presented all states in the region as being the artificial creation of colonial powers, have progressively given way to the perception that Arab states - as came to exist at various times during the past century, and in some cases much, much earlier-are here to stay. Thus we tend to analyse political developments in their state-specific dimension. 
This chapter argues that the oil rent has created a regional dynamic whereby major political developments take place at the regional rather than the single-state level. Essentially all major political movements in the region have a regional, not country-specific, dimension. The Arab Spring was a regional phenomenon, and the entire region is today involved in a regional civil war. The prospects for democratisation will also be decided at the regional level, and will essentially be influenced by the outcome of the civil war underway, which cannot be predicted.

The argument is presented in four sections followed by conclusions. The first section summarises the regional dimension of democratisation processes, and of all politics in the MENA region. The second section discusses the dynamics of oil prices and oil rent and how these have affected regional relations. The third section illustrates how regional economic integration has failed, and how conduits for regional circulation of the oil rent have not been operational or have benefited only very narrow elites. The fourth section argues that that the current regional order is in crisis, and democratic transitions will only be successful if they are accommodated at the regional level and accompanied by closer regional economic cooperation. A short conclusion closes the chapter.

The distinguishing feature of the Arab Spring is its regional character. Within weeks of the first manifestations of the movement in Tunisia, many other countries were engulfed in rapid succession: Egypt, Bahrain, Yemen, Syria and Libya. A total of five countries accounting for close to $5^{0}$ per cent of the total population of MENA were soon fully involved in the phenomenon, while others were more marginally touched-notably Oman and Jordan. In North Africa, only Algeria, which had experienced its own aborted 'Spring' twenty years earlier, and subsequently saw a very bloody civil war, was not involved. In the Levant, Iraq had been experiencing civil war conditions ever since regime change in 2003, and Lebanon has a fragile and very imperfect, yet democratic, order. The major Gulf rentier states (a grouping of which Bahrain is not a member) were almost untouched.

The regional dimension of democratic transitions has often been postulated and tested in the literature (Kuru, 2014; Freund and Jaud, 2013; Elbadawi et al., 2011). It is frequently found that the regional environment has an important bearing on the outcome of individual countries' transitions: democratisation is facilitated in regions where democracy prevails, and more difficult where authoritarian regimes are numerous. There clearly is an imitation effect, and also open support for similar regimes — at least in the case of 
authoritarian regimes, which tend to fear 'democratic contagion' and support each other more effectively than democracies do. We have seen the same in the Gulf Cooperation Council (GCC-encompassing Bahrain, Kuwait, Oman, Qatar, Saudi Arabia and the United Arab Emirates), a regional body created with the objective of ensuring mutual support among patrimonial monarchies, which quickly intervened to terminate the popular revolt in Bahrain.

Thus, regional influence is not new, but the speed with which the democratisation contagion spread during the Arab Spring was unprecedented, and justifies the quest for regional, rather than purely national causes and interpretations. Looking forward, it is apparent that the battle between democracy and authoritarian rule is also being fought and will be decided at the regional level. In MENA, all domestic politics have a regional impact, and no country's internal equilibria can be independent of regional developments (Luciani and Salamé, 1988). Political permeability inevitably turns the region into an arena for conflict rather than compromise and cooperation. It is the very close interdependence of domestic and regional affairs-close to an extent that has no parallel in any other region of the world - that makes it inevitable that MENA states will be involved in each other's internal affairs.

The region has known 'democratic exceptions' in a context of prevailing authoritarian rule. Israel has been the most prominent case, and in the economic sphere it has been almost completely alienated from its regional environment while pursuing integration with the United States of America (US), Europe and other regions. Lebanon has maintained a democracy, while being constantly on the brink of civil war, in which constitutional dictates are ignored more often than not. Tunisia might possibly also succeed in consolidating a democracy against the regional tide, and pursue a strategy of economic integration with Europe rather than its Arab neighbours. But these are exceptions, and fragile exceptions at that-Israel apart.

At the regional level, the battle is raging: while civil wars are being fought in only four countries (Iraq, Syria, Yemen and Libya) all other countries are in fact implicated. The whole region is engaged in a regional civil war whose active front is primarily in the four countries mentioned, but new fronts may open. And the GCC member states, which have so far succeeded in maintaining substantial control of their territory, are - in any case - active participants, contributing funding, providing weapons or, in the case of Yemen, Syria and Libya, via military involvement on the ground and from the air.

If and when the regional civil war will be resolved, economic policies will also need to be defined at the regional level. The task of providing for the reconstruction of Syria and Yemen will inevitably fall on the shoulders of the major Gulf oil exporters, just as the task of maintaining the Egyptian economy is already theirs. Iraq and Libya are also major producers and might possibly 
be able to fund their own reconstruction, but they too will need to define a regional economic strategy. The Arab civil war will inevitably define a new regional order, which will be economic as well as political.

In seeking appropriate economic strategies that may support the democratisation process - assuming democratisation will still be on the agenda at the end of the civil war - the regional dimension cannot be forgotten: purely national recipes have little chance of success.

\section{The Impact of the Oil Rent on Regional Economic Relations}

Oil has exerted a fundamental influence on inter-Arab relations, primarily because of the dialectic between oil-poor and oil-rich states. Interestingly, the oil-rich states are also relatively 'new' in terms of history, having been formed in the first half of the twentieth century, and having gained independence even later; while the oil-poor states have deeper historical roots, in the case of Egypt and Iraq even having existed for millennia (Harik, 1987). Furthermore, the oil-rich states are rentier, meaning that the state is supported by revenues accruing from abroad and independent of domestic taxation; while the oilpoor states became rentier only for a short period, as recipients of unilateral transfers from the oil-rich states in the 1970s and 8os (Luciani, 1987).

The dichotomy between oil-rich and oil-poor states (Kerr and Yassin, 1982) is certainly not the only factor in the extraordinary divisiveness of Arab regional relations, but it has been significant. Although the pan-Arab ideology, which dominated the region at least until 1967 , is not directly related to oil—it is rather a reaction to the Balkanisation of the Arab region, which, in turn, is certainly also related to oil —it quickly became entangled with it, hardening the conflict between the historically longer established, progressive, more developed, but oil-poor Arab states and the newly formed, traditional, conservative, oil-rich states of the Gulf and North Africa.

In regional relations the oil-poor states implicitly or explicitly articulated a claim to a share of the oil rent that the oil-rich states never truly accepted as legitimate. Nasser's ideology was not primarily conceived of as a tool with which to destroy the oil monarchies and assert control over their oil riches, but it was soon perceived by these monarchs as aiming precisely at this outcome. Nasser was defeated not only by his inability to deliver progress with respect to the Palestine-Israel issue, but also, and perhaps even more so, by his inability to come to terms with the oil monarchies-or, to be precise, with all oil-exporting countries in the region-even when some (like Iraq in 1958 and Libya in 1969) shed their monarchies and followed the 'revolutionary' path. He 
lost his battle when he could not prevail in the civil war in Yemen; nor was he able to overcome persistent rivalry with Iraq (even before 1967). The advent of a regime, in Libya, with strong Nasserite and pan-Arab inclinations received little more than an opportunistic and profiteering response from Egypt.

In the 1970s, the increase of the oil rent was so sudden, and its concentration so extreme, that the rentier states felt it was prudent to be generous outside, as well as inside, their borders. They therefore created institutions to redistribute a share of the rent internationally and engaged in granting direct subsidies to neighbouring governments. Jordan, Syria, the Palestine Liberation Organization, and - until it made peace with Israel-Egypt were major beneficiaries of these direct grants. Later, Iraq became a recipient during its protracted war with Iran.

However, the effectiveness of such generosity in purchasing lasting goodwill was dubious, to say the least. Iraq's decision to invade Kuwait, and the attitude that Jordan, Yemen, or the Palestinians adopted on that occasion, proves that generosity sometimes breeds resentment. More recently, the fact that alQaeda turned against the Saudi regime is another demonstration of a client turning against its patron.

So, after a short period of time during which the tide of the rent rose so high that it covered the entire region and almost every government became rentier (in the sense of being primarily occupied with capturing oil or strategic rents in the form of direct grants), the region went back to a condition that was common before 1973 - that is, being dominated by the dynamics between rentier and non-rentier, or oil-rich and oil-poor, states, and the seeming impossibility of integration between them.

The Arab Gulf States reacted to the Iraqi invasion of Kuwait and the positions taken by several neighbouring countries by radically revising their previously generous attitude, expelling massive numbers of immigrants from the other Arab countries and establishing the GCC as a club of rentier monarchs pursuing an integration project separate and independent from the rest of the region.

The decade of low prices from 1990 to 2000 marked a shift in the attitudes and economic policies of rentier and non-rentier governments alike. The rentiers became more aware of the urgent need for economic diversification, and increased reliance on private sector initiatives, which entailed, among other things, promoting regional trade and investment opportunities. The nonrentiers progressively yielded to international pressure to open up their economies and espouse orthodox fiscal and monetary policies. By the end of the decade, the Greater Arab Free Trade Area (GAFTA) was launched (1997) to pursue an increase in intra-regional trade, which was historically abnormally low. Yet 
the scar of the mass expulsion of Arab immigrants was only minimally healed: an emphasis on reducing costs increased the attractiveness of importing especially South Asian labour, and limiting the role of Arab immigrants to those occupations where knowledge of the language was necessary or at least a very significant advantage.

But the US-led coalition's intervention in Iraq in 2003 again changed the region's economic environment. There is a close connection between regime change in Iraq and the onset of the oil price cycle that began in 2004 and came to a dramatic end in the latter part of 2014. At the turn of the century oil prices were recovering from the abysmally low levels reached in 1998-99, and the dominant narrative was that of peak oil. Following the terrorist attacks of September 2011 some tension emerged on the markets due to a fear for oil supplies-Saudi Arabia at that time being portrayed as part of the problem rather than part of the solution. However, in the run-up to the allied intervention in Iraq the expectation was that the demise of the Saddam regime would bring an end to the sanctions then in place against the country, lead to the opening of Iraq to investment from international oil companies, and trigger a rapid increase in oil production. As it became apparent that the outcome of the Iraqi adventure was very much different from what had been expected, oil prices started increasing gradually. The upward trend found little immediate resistance: demand for oil showed no sign of decreasing, indeed China's appetite for imported oil exploded; industrial countries were not plunged into recession; and alternative sources of oil were not immediately forthcoming. The market became convinced that prices could rise much higher, and eventually created a bubble. The financial crisis subsequent to the collapse of Lehmann Brothers suddenly drained liquidity from the oil futures market, leading to a collapse in prices in the latter part of 2008-but this proved temporary. Prices recovered quite rapidly and kept climbing until 2011. The outbreak of the Arab Spring contributed to again creating a fear that oil supplies from the Middle East might be seriously disrupted, although this was in fact not the case.

We can therefore identify a clear oil price cycle, which began approximately in 2004 and came to an abrupt end in 2014. This price cycle had momentous consequences in the Middle East region: it further emphasised the distance between the oil exporters of the Gulf and the rest of the region, and created the underlying conditions for the regional upheaval of the Arab Spring.

It is clear that the period of very high prices led to greater regional instability rather than having the opposite effect. It enhanced the distance between the major oil exporters and the rest of the region, and the income concentration within rentier oil exporters non-rentiers alike. In the major oil exporting 
countries, governments relied again on old and ineffective redistribution policies, which by and large further benefited the haves without offering a significant improvement in the lot of the have-nots. As discussed elsewhere in this volume, ${ }^{1}$ low prices for energy products have a regressive impact on income distribution. Infrastructure expenditure benefits local contractors; increased spending leads to higher prices for housing, benefiting real estate investors and damaging the poorer nationals for whom cheap housing is not provided; even the very generous schemes to support nationals studying abroad only benefit a minority, while the majority of adolescents get only mediocre education and are not ready for gainful employment; youth unemployment worsened, as nationals were squeezed out of the market by excessively low wages paid to unqualified expatriates from South Asian countries.

In the non-rentier states, the development model of Dubai and the other Gulf countries became hegemonic: political elites nurtured cronies whose role was to attract investment from the Gulf, offering opportunities to invest in real estate and luxury tourism, and to engage in financial speculation. The economies of the non-rentier countries experienced very satisfactory growth, but the quality of increased investment and value added did not allow for trickledown to occur.

As I have argued elsewhere (Luciani, 2016) the Arab Spring's eruption and regional dimension cannot be easily explained unless we take into account the dynamics of income distribution at the regional level, not just within each country in the region. National statistics do not show any appreciable worsening of income distribution, but Alvaredo and Piketty (2014) convincingly argue that the data sources that are currently available at the national level in Egypt or other MENA countries are insufficient to derive reliable estimates of top income shares, and that income inequality is extremely large at the level of the Middle East taken as whole. It is the perception of such growing inequality, further fuelled by the growing role of regional media and the constant image of Dubai-style success that they project, that ignited resentment and revolt against the incumbent authoritarian regimes.

Now that the tide of oil prices has turned, will tensions decrease? Reduced financial means may possibly encourage a relatively speedier resolution of the regional civil war, but political stabilisation will require a regional economic order that promises opportunities for all and allows for reducing economic disparities.

1 El-Katiri and Fattouh, this volume; Hertog, this volume. 
Ever since the heyday of pan-Arabism, economic integration within the Arab region has been a recurring theme and objective, but accomplishments remain profoundly disappointing. It is difficult to envisage a significant improvement in the development prospects of individual Arab countries unless greater success is achieved in pursuing regional integration.

In theory, the Arab region should be expected to provide a model of successful regional economic integration. This is because resources are so unevenly distributed: individual countries within the region face obvious difficulties due to the lack of one or other ingredient in the development recipe, and are thus clearly complementary with each other. Indeed, we have countries with oil resources, but that are mostly thinly populated and largely desert; countries with large populations but limited agricultural potential and little or no mineral resources; and countries with significant agricultural potential, which cannot be fully exploited because of a lack of capital or adequate market access. Greater integration along the axes of movements of capital, labour and merchandise trade is an obvious opportunity.

Yet, little effort has gone into actually pursuing regional economic integration. Endemic political conflict and rivalry, in particular between immediate neighbours, has led to a subordination of economic to political considerations, and systematic reticence towards greater interdependence. The nature of oil as an essentially global commodity trivialises the importance of stable bilateral trade relations, and creates the illusion that a global trade orientation in the absence of regional trade may be sufficient to deliver development. Although Israel has effectively succeeded in developing a modern economy with significant points of excellence while being almost completely isolated from trade with its neighbours, the same experience cannot be replicated elsewhere in the region. The major oil exporters have pursued an industrialisation strategy based on adding value to crude oil and developing refining, petrochemical and other energy-intensive industries that also are structurally global and independent of trade relations with neighbours-but there are evident limits to this model. These same countries also prefer to seek close bilateral trade ties with distant countries - be they in the Americas, in Europe or in the Far East-but are notably reserved about increasing imports from neighbours.

\subsection{Merchandise Trade}

Currently the region is covered by a complex array of trade agreements, many of which have never been implemented and are effectively dead, but continue to exist on paper. The region-wide agreement currently in force and still being 
implemented - where security and political conditions allow—is the GAFTA, which was established in 1997 and progressively led to some reduction of tariffs on bilateral trade. Among sub-regional agreements, one should of course mention the Gulf Cooperation Council and the Agadir Agreement (encompassing Egypt, Jordan, Morocco and Tunisia). The former group decided, already when it was formed in 1981, to establish a common market, but has not yet succeeded in doing so; ${ }^{2}$ the latter is an example of deep integration but as the four countries involved are not contiguous, trade between them is hindered by logistical difficulties.

In addition, there have been attempts to establish trade liberalisation agreements in the context of the Barcelona Process between the EU and the 'Southern Neighbours'3 (a set that does not include all Arab countries, but only those with a shore on the Mediterranean, plus Jordan; notably excluding member countries of the GCC); and between the Us and a select number of Arab countries (Bahrain, Jordan, Morocco and Oman). The latter, dubbed Middle East Free Trade Area (MEFTA), was launched in 2003 by the Bush Administration in the context of other initiatives aimed at reshaping the Middle East (regime change in Iraq being the first and foremost of these), but appears to have been largely abandoned by the Obama Administration. In addition, the EU has officially been pursuing a free trade area with the GCC (separate from the Barcelona Process), but has never succeeded in finding sufficient common ground with the intended partners.

It is, in the literature, well established that trade agreements between the $\mathrm{EU}$ and the Southern neighbourhood countries have led to an increase in EU exports towards these partner countries, but not of partner countries' exports to the EU (Parra et al., 2016; Gylfason et al., 2015). Empirical analysis shows that this result might change if trade in agricultural products were liberalised alongside trade in industrial products, but this is not something that the EU has been ready to contemplate.

Notwithstanding its slow implementation, the literature has also found that GAFTA has had a moderately positive impact on South-South trade, at least until the eruption of the Arab Spring and the political disarray that followed. In contrast, the findings on the effect of the Agadir Agreement are not unanimous:

2 A customs union was announced in 2003 and the common market was officially launched in 2007 and should have started the following year, but in practice the member countries have not surrendered sovereignty for all external trade matters to a central authority such as the GCC secretariat.

3 The Barcelona Process or Euro-Mediterranean Partnership was launched in 1995. In 2008 the Union for the Mediterranean (UfM) was created to inject new life into the process, but this objective can hardly be said to have been achieved. 
Gylfason et al. (2015) find that the agreement has stimulated horizontal trade, notwithstanding the fact that signatories are not contiguous countries, and conclude that 'deep and comprehensive free trade agreements between contiguous and economically large countries could increase trade flows significantly' The limited importance of horizontal trade between Arab countries is therefore attributable to conflicts between immediate neighbours, which stifle proximate trade liberalisation. The authors therefore propose to reverse the tide by aiming at a deep and comprehensive trade agreement between Egypt, Israel and Jordan, which they deem politically feasible because these three countries have signed peace treaties with each other-a proposal that is optimistic at best. In contrast, Parra et al. (2016) do not find a beneficial effect of the Agadir Agreement.

Following the Arab Spring and the drift towards a full-scale regional civil war, attention to trade liberalisation is no longer a priority. Yet it is difficult to imagine that a virtuous circle of democratisation can be supported in the absence of a convincing project for trade liberalisation. Is it conceivable that this might be sponsored by outside actors, such as the European Union (EU) or the us? Both attempted to do so in the past, the Eu through the Barcelona Process and the us through MEFTA. In each case, the respective projects suffered from their partial nature, being addressed to subsets of the membership of the Arab League and therefore being viewed as having a divisive rather than an integrative impact on the region. Such schemes have justifiably been accused of aiming to impose a hub-and-spoke style trade pattern that would cement the dependence of Arab countries on either the EU or the Us, and their isolation from each other. It is possible that a joint EU-US initiative encompassing all Arab countries and aiming at creating serious opportunities for regional integration might, in a context of regional pacification, succeed in finally putting in place adequate agreements, including the necessary supranational institutions and enforcement mechanisms. The conditions for such an initiative do not exist today and have not existed for the past half-century (since at least 1967); they may not be reunited in the future either. Yet, the recurrent temptation to cut corners and launch partial initiatives will, in all likelihood, doom such initiatives to failure.

\subsection{Movements of Labour}

Frustrations with trade liberalisation have in the past led to the conclusion that in the case of the Arab countries economic integration should rather start with movements of factors of production-labour and capital - than with merchandise trade. This view appeared to have empirical support in the $1970 \mathrm{~s}$ and 1980s, when inter-Arab migrations reached their maximum intensity. At 
that time, migration was viewed as bringing about a new Arab social order (Ibrahim, 1982) through its impact on family structures and its opening the possibility of capital accumulation for the middle and lower income classes of the sending countries. But this vision was soon aborted: Iraq, a major receiving country, became embroiled in an extended and bloody conflict with Iran, while oil prices collapsed in 1985 precipitating expenditure cuts in all major oil-exporting countries. Then, in 1990, Iraq invaded Kuwait, and some of the major senders of migrant labour-notably Jordan, the Palestinian Territories and Yemen-aligned themselves in support of Saddam Hussein. The reaction was immediate and radical: Saudi Arabia expelled approximately 800,000 Yemeni workers before the end of the year, having cancelled the rule that allowed Yemeni nationals to enter the kingdom without a visa and work without a sponsor (Ayalon, 1990, 725). ${ }^{4}$ In addition, 200,000 Jordanians, 150,00o Palestinians, and nearly all Sudanese were effectively expelled from the kingdom (Richards and Waterbury, 2007). In Kuwait, half of the Palestinian population, estimated at 400,00o before the invasion, either fled or was expelled. The rest were also gradually pushed out, and by 2012 the Palestinian population of $\mathrm{Ku}-$ wait was estimated to be barely 80,000.

In fact, the relative importance of other Arabs in the total expatriate population in the Gulf had been declining systematically even before 1990 as shown in Tables 11.1, 11.2 and 11.3.

TABLE 11.1 Arab share in foreign populations 1975-2015

\begin{tabular}{lccccc}
\hline & 1975 & 1985 & 1996 & $\mathbf{2 0 0 2} / 4$ & $\mathbf{2 0 1 0} / \mathbf{1 5}$ \\
\hline Bahrain & 22 & 15 & 12 & 15 & 8.4 \\
Kuwait & 80 & 69 & 33 & 30 & 26.5 \\
Oman & 16 & 16 & 11 & 6 & 2.6 \\
Qatar & 33 & 33 & 21 & 19 & 30.2 \\
Saudi Arabia & 91 & 79 & 30 & 33 & 46 \\
UAE & 26 & 19 & 10 & 13 & 18.4 \\
GCC & 72 & 56 & 31 & 32 & 30 \\
\hline
\end{tabular}

SOURCES: FOR 1975 TO 2004: KAPISZEWSKI, 2006; FOR 2010/15: EUROPEAN UNIVERSITY INSTITUTE, MIGRATION POLICY CENTRE, GULF LABOUR MARKETS AND MIGRATION DATABASE (GLMM DATABASE-HTTP://GULFMigRATION.EU/GLMM-DATABASE/).

4 In later years Yemenis continued to move to the kingdom in many cases illegally (without a visa) and this led to large-scale expulsions as recently as in 2013 and 2015. 
TABLE 11.2 Estimates of the number of foreign nationals (Arab nationalities), by country of residence in GCC member countries (2010-2014)

\begin{tabular}{|c|c|c|c|c|c|c|c|}
\hline Destination & Bahrain & Kuwait & Oman & Qatar & Saudi Arabia & UAE & GCC \\
\hline Year & 2014 & end 2012 & 2010 & $2013^{-2014}$ & 2013 & $2013-2014$ & \\
\hline \multicolumn{8}{|l|}{ Origin } \\
\hline Algeria & n.a. & 845 & n.a. & n.d. & n.a. & $10,000^{(e)}$ & 10845 \\
\hline Egypt & 20,000 & 482,692 & 29,877 & $18,0000^{(b)}$ & $1,370,000^{(d)}$ & $400,000^{(e)}$ & $2,482,569$ \\
\hline Iraq & n.a. & 15,262 & 4,159 & 8,976 & 20,000 & $5^{2,000^{(\mathrm{e})}}$ & 100,397 \\
\hline Jordan & 7,000 & 55,081 & 7,403 & $40,000^{(b)}$ & 250,000 & $200,000^{(\mathrm{e})}$ & 559,484 \\
\hline Lebanon & $2,300^{(a)}$ & 42,586 & n.a. & $25,000^{(b)}$ & 160,000 & $100,000^{(e)}$ & 329,886 \\
\hline Mauritania & n.a. & 142 & n.a. & n.d. & n.a. & $5,000^{(e)}$ & 5,142 \\
\hline Morocco & $800^{(a)}$ & 3,495 & n.a. & $9, \mathrm{Ooo}^{(\mathrm{b})}$ & $20,000^{(a)}$ & 14,000 & 47,295 \\
\hline Palestine & $5,000^{(a)}$ & 8,072 & n.a. & $20,500^{(b)}$ & 500,000 & $15^{0,000^{(e)}}$ & 683,572 \\
\hline Sudan & $14, \mathrm{OOO}^{(\mathrm{a})}$ & $4,55^{1}$ & 6,867 & $42,000^{(b)}$ & 500,000 & $75, \mathrm{OOo}^{(\mathrm{e})}$ & 642,418 \\
\hline Syria & 3,000 & 135,554 & n.a. & $60,000^{(\mathrm{c})}$ & $1,000,000^{(c)}$ & $242,000^{(c)}$ & $1,440,554$ \\
\hline Tunisia & $500^{(a)}$ & 2,863 & n.a. & $15, \mathrm{OOo}^{(\mathrm{b})}$ & $12,000^{(a)}$ & 4,500 & 34,863 \\
\hline Yemen & 4,700 & 10,762 & n.a. & $40,000^{(a)}$ & 800,000 & $90,000^{(e)}$ & 945,462 \\
\hline TOTAL & 57,300 & 761,905 & 48,306 & 440,476 & $4,632,000$ & $1,342,500$ & $7,282,487$ \\
\hline
\end{tabular}

Figures for migrants in the GCC may be overestimated due to the inclusion of a large share of Gulf-born (second and third generation) non-nationals.

Palestinians are holders of travel documents.

Some of the figures quoted are unverifiable estimates. Therefore, they should be taken as indicative only and should not be used for statistical purposes.

Unless stated otherwise, receiving countries' estimates are from relevant tables in the POP section of the EUI Migration Policy Centre, GLMM database.

(a) United Nations (2013), revision total migrants' stocks by origin and destination countries.

(b) Snoj, J. (2013)'Population of Qatar by nationality' (Doha: BQ Magazine) December, http://www.bqdoha.com/2013/12/population-qatar (accessed on 8 April 2016) and http:// gulfmigration.eu/qatar-estimates-of-foreign-nationals-residing-in-qatar-by-country-ofcitizenship-selected-countries-2014/ (accessed on 8 April 2016).

(c)Latestfigures available as of October 2015, in:DeBel-Air,F.(2015)'ANote on Syrian Refugeesin the Gulf:Attempting to Assess Data and Policies', G LM ExplanatoryNote, GLMM-EN-No.11/2015. http://gulfmigration.eu/media/pubs/exno/GLMM_EN_2015_11.pdf(accessed on8April2016). (d) Official estimate: Egyptian workers in Saudi Arabia number 968,ooo (end of 2013). https:// www.middleeastmonitor.com/news/africa/14187-egyptians-represent-40-per-cent-o--saudiarabias-total-expatriate-workforce (accessed on 8 April 2016).

Estimates of family dependents: in the absence of any indication of the ratio of worker to family dependents in the UAE, we use data available for Kuwait in 2012: 2.4 workers per family dependent. Estimates of Egyptians (total): $968,000+(968,000 / 2.4)=1,371,000$.

(e) Snoj, J. (2015)'UAE's population by nationality' (Doha: BQ Magazine) April 12. Table as of December 15, 2015 . 
TABLE 11.3 Total population and percentage of nationals and non-nationals in Gcc countries (2010-2015)

\begin{tabular}{|c|c|c|c|c|c|c|}
\hline \multirow[t]{2}{*}{ Country } & \multirow[t]{2}{*}{ Date/period } & \multirow{2}{*}{$\begin{array}{l}\text { Total } \\
\text { population }\end{array}$} & \multirow[t]{2}{*}{ Nationals } & \multirow{2}{*}{$\begin{array}{l}\text { Non- } \\
\text { nationals }\end{array}$} & \multicolumn{2}{|c|}{$\%$ in total population } \\
\hline & & & & & Nationals & Non-nationals \\
\hline Bahrain $^{(1)}$ & mid-2014 & $1,314,562$ & 630,744 & 683,818 & 48.0 & $5^{2.0}$ \\
\hline Kuwait $^{(2)}$ & 31 March 2015 & $4,161,404$ & $1,283,726$ & $2,877,678$ & 30.8 & 69.2 \\
\hline $\mathrm{Oman}^{(3)}$ & 25 March 2015 & $4,149,917$ & $2,324,327$ & $1,825,590$ & 56.0 & 44.0 \\
\hline Qatar $^{(4)}$ & April 2010 & $1,699,435$ & 243,019 & $1,456,416$ & $14 \cdot 3$ & $85 \cdot 7$ \\
\hline Saudi Arabia ${ }^{(5)}$ & mid-2014 & $30,770,375$ & $20,702,536$ & $10,067,839$ & $67 \cdot 3$ & 32.7 \\
\hline United Arab & mid-2010 & $8,264,070$ & 947,997 & $7,316,073$ & 11.5 & 88.5 \\
\hline \multicolumn{7}{|l|}{ Emirates $^{(6)}$} \\
\hline Total* & & $5^{0,359,763}$ & $26,132,349$ & $24,227,414$ & $5^{1.9}$ & 48.1 \\
\hline
\end{tabular}

* Total provides the sum of population numbers at different dates between April 2010 and March 2015. It is not exactly the total population at any of these dates.

1 -Definition

Non-nationals are:

1.1-Persons of the nationality of a foreign state other than the GCC state of residence, or bearing no proof of nationality from any given state (stateless persons and holders of refugee status and travel document in a third country);

1.2- Holders of residence permits residing in the given GCC country at the date of census, as per the definition of residence used in each of the countries. Figures for Bahrain, Saudi Arabia and the UAE are estimates.

2-Sources of data:

Unless stated otherwise, the source is EUi Migration Policy Centre, GLMM database.

(1) Bahrain Central Informatics Organisation (CIO), cro's website, 'Statistics' and 'Population' sections http://www.data.gov.bh/en/ResourceCenter.

(2) Kuwait Public Authority for Civil Information (PACI), http://www.paci.gov.kw/en/ (accessed on 31 March 2015).

(3) Sultanate of Oman National Centre for Statistical Information (NCSI), http://www.ncsi .gov.om/ (accessed on 5 March 2015).

(4) Qatar Statistics Authority (QSA), Census 2010 http://gulfmigration.eu/population-by -nationality-qatari-non-qatari-census-1970-2010/ (accessed on 8 April 2016).

(5) Saudi Arabia Central Department for Statistics and Information (CDSI), estimates. http://www.cdsi.gov.sa/ (accessed on 8 April 2016).

(6) UAE National Bureau of Statistics (NBS), estimates http://www.uaestatistics.gov.ae/ (accessed on 8 April 2016). 
Kapiszewski has pointed to the political activism of early Arab migrants and to the pan-Arab beliefs that they entertained:

Many young Arabs regarded borders in the Middle East as artificial lines imposed by Western imperialists, and, consequently, expected them to be eliminated. Another popular pan-Arab view, that of a single Arab nation in which labor "circulates" freely, was also rejected by the Gulf governments for security reasons. Yet another problem was related to the regional distribution of the oil-generated wealth. Whereas the oilproducing countries which preferred to retain that wealth began to link the entitlement of oil revenues to state sovereignty, poorer states increasingly stressed their Arab identity as a good reason to demand their share in the revenues: Iraq even used the oil-related arguments as a justification to invade Kuwait in 1990.

KAPISZEWSKI, 2006, 6-7

Such sentiment has not dissipated to this date and is very central to the Arab civil war.

The declining importance of Arab migrants is even more striking when viewed in the context of growing total expatriate numbers. From the point of view of the composition of their populations, cities like Dubai, Abu Dhabi or Doha have effectively become South Asian. The lack of a preference for other Arabs - or even positive discrimination against them — has been a huge lost opportunity for regional economic integration, including from the point of view of trade ties and capital movements (which migration would have facilitated). But the attitude of the Gulf countries has, if anything, shifted in the opposite direction: increasingly some of the Gulf States have tended to deprive even large groups of citizens of their nationality, in order to punish dissidents.

\subsection{Movements of Capital}

With little progress on the trade front and the declining relative importance of inter-Arab migration, the only dimension of regional integration remaining is capital movements. These did intensify progressively as non-oil Arab countries adopted orthodox fiscal and monetary policies, and the major oil exporters were flush with liquidity thanks to rapidly growing oil prices. InterArab investment grew significantly until 2008 (with an exceptional peak in 2005, Figure 11.1), then collapsed in conjunction with the global financial crisis. Investment picked up again beginning in 2010, but then the effects of regional political turmoil began to be felt. 


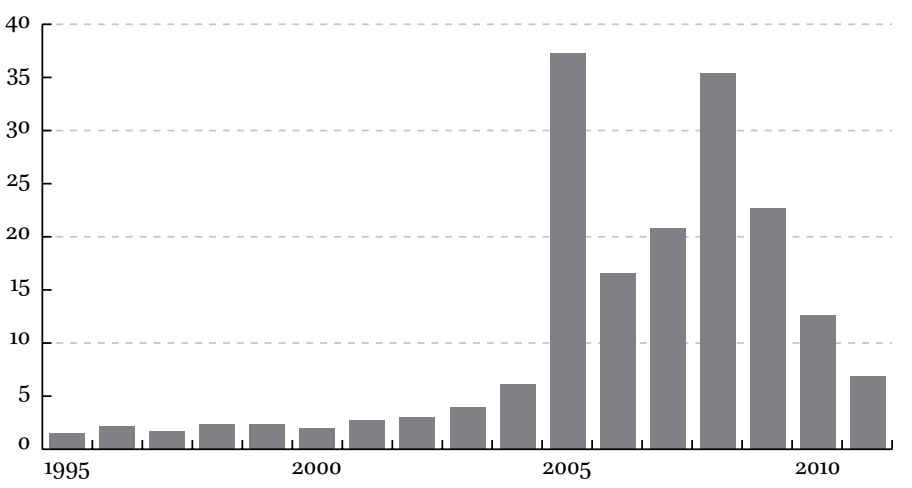

FIGURE 11.1 Inter-Arab foreign direct investments (FDI) inflows (USD

billion, 1995-2011)

SOURCE: ARAB INVESTMENT AND EXPORT CREDIT

GUARANTEE CORPORATION, 2011.

Data on the accumulated stock of inter-Arab investment to the end of 2011 (Table 11.4) point to a prevalence of cross investment within GCC member states, with Saudi Arabia being the main recipient country, due to its larger internal market. Outside the GCC, Sudan, Egypt, Lebanon and Algeria have been major recipients, while Jordan, Syria, Yemen, Tunisia and Morocco have remained at the margins.

Much of this distribution can be explained on the basis of the size of the respective economies, the attractiveness of investment conditions, political/ security considerations, or proximity. In this respect the figure for Algeria is a little surprising, because the country has neither a friendly investment environment nor proximity to the Gulf.

With respect to sectors, it is found that inter-Arab investment concentrates heavily in services (tourism, banking, telecommunications...), which absorb close to 70 per cent of the total, while industry absorbs about a quarter.

The 'push factor' of high oil prices generating large surpluses and abundant liquidity is confirmed by data for 2012 (Table 11.5), showing the large investment from Qatar in Algeria, Egypt and Tunisia. The contrast between Qatar and the United Arab Emirates (UAE) is interesting; the latter being evidently more reserved about investing in the region.

It is clear from these figures that inter-Arab investment remains highly concentrated on a few large-scale projects, frequently initiated by state-owned entities. As such, it remains an unstable and occasional source of funding, albeit not an unimportant one. The role of private investors and industrial 
TABLE 11.4 Inward inter-Arab FDI stocks as of end 2011-individual country shares

\begin{tabular}{lr}
\hline Saudi Arabia & 27.06 \\
Sudan & 13.21 \\
Egypt & 11.28 \\
Lebanon & 8.38 \\
Algeria & 7.81 \\
Bahrain & 7.66 \\
UAE & 6.38 \\
Morocco & 3.66 \\
Jordan & 2.61 \\
Tunisia & 2.44 \\
Kuwait & 2.08 \\
Oman & 1.94 \\
Syria & 1.85 \\
Yemen & 1.68 \\
Libya & 0.75 \\
Palestine & 0.73 \\
Qatar & 0.22 \\
Djibouti & 0.19 \\
Iraq & 0.07 \\
\hline
\end{tabular}

SOURCE: ARAB INVESTMENT AND EXPORT CREDIT GUARANTEE CORPORATION, 2011.

enterprises is minor, and the employment effects on the receiving countries, effects about which very little is known, are likely to be minor.

In short, so far inter-Arab investment has failed to be the engine of regional growth that many expected and hoped that it might become. In particular, the idea of 'triangulation' (allying finance from the Gulf and other major oil exporters with industrial know-how from Europe, the us or elsewhere and an abundant labour supply in oil-poor Arab countries) has not made any progress at all in practice.

\section{Conclusion: The Unresolved Regional Political Order}

As we look forward to a potential end to the Arab civil war the need for a new regional political and economic order seems inescapable. In a recent report 


\section{Destination Origin of FDI flows}

\begin{tabular}{llllll}
\hline Bahrain Kuwait Oman Qatar & $\begin{array}{l}\text { Saudi } \\
\text { Arabia }\end{array}$ & UAE Egypt
\end{tabular}

\begin{tabular}{|c|c|c|c|c|c|c|}
\hline Algeria & & & 738 & & 91 & \\
\hline Egypt & & 196 & 640 & 160 & $73^{8}$ & \\
\hline Jordan & & 59 & 18 & 237 & $5^{0}$ & \\
\hline Lebanon & & & 1 & 11 & 38 & 132 \\
\hline Libya & 21 & & 129 & & 15 & \\
\hline Morocco & & 65 & 15 & 105 & 73 & \\
\hline Syria & 83 & 63 & 36 & & 60 & \\
\hline Tunisia & & 17 & 457 & & & \\
\hline
\end{tabular}

SOURCE: NOUTARY AND TABET, 2013.

proposing three scenarios for the future of the Arab region in 2025, the optimistic scenario is introduced as follows:

The implementation of a Greater Arab Free Trade Area (GAFTA), coupled with a reduction of $5 \%$ in transport costs and the replacement of $20 \%$ of foreign labour in the Gulf by Arab workers led to an important U-turn in Arab economies. In Egypt, unemployment rates among skilled workers dropped by $8 \%$; in Morocco, by $7.2 \%$, in Tunisia by $6.9 \%$. GDP rates grew in all Arab countries, but particularly in Egypt (whose GDP grew by $6.2 \%$ ) and Tunisia (4.2\%).

GAUB AND LABAN, 2015, 37

Such emphasis on the regional dimension of economic growth and the importance of integration through trade and migration is fully justified. Individual Arab countries can move towards democracy and implement economic reforms to support such a transition, but in the absence of a convincing and bold regional integration strategy Arab youth will still focus primarily on moving out of the region.

At the same time, the implementation of a new regional economic order also requires a new political order. The main difficulty in this respect is that those countries in the region that have the most economic assets and toolsthe major Gulf exporters - are ruled by patrimonial monarchies rather than political forces, and their model of governance cannot be exported. Indeed, 
patrimonial monarchies find it difficult to engage in regional cooperation that requires any kind of devolution of sovereignty to regional institutions, as demonstrated by the lacklustre progress of the GCC.

In the wake of the Arab Spring, in 2011 Saudi Arabia's King Abdullah called for the transformation of the GCC into a union-a project whose exact implications were never spelled out precisely, although it meant some form of transition from interstate cooperation to at least partial devolution of sovereignty. The call was not met with enthusiasm by fellow GCC member monarchs, and has failed to make any progress. The idea of Gulf integration has significant support in GCC member countries, primarily in business circles-although many would not want to see the Saudi brand of Wahhabism and mores imposed on the rest of the region.

Again in 2011, the GCC invited Jordan and Morocco to become members, much to the surprise of the latter. This too was an attempt at strengthening the GCC and showing that it had regional power of attraction beyond the Arabian peninsula: both Jordan and Morocco are monarchies, of course, but in both countries power is not exclusively centralised in the hands of the monarch and elections are regularly held. Not much progress in this direction has been made.

Finally, Yemen applied for membership of the GCC in 2015, following the launch of the Saudi military intervention in the country. ${ }^{5}$ Yemen is obviously seeking free access for its citizens to GCC labour markets, and an opportunity to attract financial support and private direct investment. By the same token, the idea of Yemeni membership constitutes a big problem for the GCC, which has been accused of having many times missed opportunities to integrate their southern neighbour. The political obstacles to the country's membership of the GCC are only too obvious, as Yemen's political reality is totally incongruous with that of the GCC; nevertheless, refusing to offer to its people a reasonable opportunity for development is tantamount to allowing a security time bomb to grow increasingly dangerous, situated at the door of the GCC.

With respect to other countries in the region, the GCC and its members aim to support 'friends' that reproduce authoritarian styles of governance. That such friends are not always well chosen is unfortunately a reality, President alSisi being the foremost example. In recent years, Qatar has tended to support its own 'friends', which are not the same as those that the UAE or Saudi Arabia support—a rift that has been superficially but not substantially overcome.

5 'Rather than scoffing at the idea of Yemeni membership in the GCC, the Gulf Arab nations should realize that closer integration of the states of the Arabian Peninsula is a historic opportunity —one that they have failed to seize, time after time'. Farea al-Muslimi (2016)'A History of Missed Opportunities: Yemen and the G CC', Carnegie Endowment for International Peace, http://carnegieendowment.org/syriaincrisis/?fa=62405 (accessed on 5 February 2016). 
And yet, neither the perspective of a 'fortress GCC' nor that of Arab integration without the GCC has much potential. Kuwait, Qatar or the UAE may aim at isolating themselves from the regional security environment, positioning themselves as political free zones between a troubled region and the global environment; but Bahrain, Oman and Saudi Arabia are inevitably exposed and impacted by regional politics. Conversely, an Arab regional project that does not include the major oil exporters would lack the main growth engine that the financial, labour and consumer markets of the GCC can offer.

It is, then, difficult today to share the vision of the optimistic scenario referenced at the beginning of this section, just as it is difficult to foresee the end of the Arab civil war any time soon. Yet civil wars eventually do end, and the future of the region depends entirely on the political order that will follow.

\section{References}

Alvaredo, F. and T. Piketty (2014) Measuring Top Incomes and Inequality in the Middle East: Data Limitations and Illustration with the Case of Egypt, Working Paper Series 832 (Cairo: Economic Research Forum), http://piketty.pse.ens.fr/files/Alvaredo Piketty2014ERF.pdf (accessed on 17 March 2016).

Arab Investment and Export Credit Guarantee Corporation (2011). Investment Climate in Arab Countries, 2011 (Safat: The Arab Investment and Export Credit Guarantee Corporation), http://www.iaigc.net/UserFiles/file/en/archives/annual_reports/ Climate-2011-English.pdf (accessed on 8 April 2016).

Ayalon, A. (ed.) (1990) Middle East Contemporary Survey, Volume 14, (Boulder: Westview Press).

De Bel-Air, F. (2015) 'A Note on Syrian Refugees in the Gulf: Attempting to Assess Data and Policies', glmm Explanatory Note, glmm-en - No. 11/2015. http://gulfmigration.eu/media/pubs/exno/GLMM_EN_2015_11.pdf (accessed on 8 April 2016).

Elbadawi, I., S. Makdisi and G. Milante (2011) 'Explaining the Arab Democracy Deficit' in I. Elbadawi and S. Makdisi (eds.) Democracy in the Arab World: Explaining the Deficit, (Abingdon and New York: Routledge).

Freund, C. and M. Jaud (2013) 'On the Determinants of Democratic Transitions' Middle East Development Journal 2013(05) DoI: 10.1142/S1793812013500053.

Gaub, F. and A. Laban (eds.) (2015) Arab Futures: Three Scenarios for 2025 European Union Institute for Security Studies Report No.22 (Paris: EU Institute for Security Studies) http://www.iss.europa.eu/uploads/media/Report_22_Arab_futures.pdf (accessed on 8 April 2016).

Gylfason, T., I. Martínez-Zarzoso and P.M. Wijkman (2015) 'Can free trade help convert the "Arab Spring" into permanent peace and democracy?, Defence and Peace Economics, 26(3), DOI: 10.1080/10242694.2014.886433. 
Harik, I. (1987) 'The Origins of the Arab State System' in G. Salamé (ed.) The Foundations of the Arab State (London and New York: Croom Helm).

Ibrahim, S.E. (1982) The New Arab Social Order-A study of the social impact of oil wealth (Boulder: Westview Press).

Kapiszewski, A. (2006) Arab versus Asian Migrant Workers in the Gcc Countries, United Nations Expert Group Meeting on International Migration and Development in the Arab Region, Population Division, (Beirut: Department of Economic and Social Affairs, UN Secretariat), UN/POP/EGM/2006/02.

Kerr, M.H. and E. Yassin (1982) Rich and Poor States in the Middle East (Boulder: Westview Press).

Kuru, A.T. (2014) 'Authoritarianism and Democracy in Muslim Countries: Rentier States and Regional Diffusion' Political Science Quarterly, 129(3), DOI: 10.1002/polq.12215.

Luciani, G. (1987) 'Allocation vs. Production States: A Theoretical Framework' in B. Hazem and G. Luciani (eds.) The Rentier State (London and New York: Croom Helm).

Luciani, G. (2016) 'On the Economic Causes of the Arab Spring and its Possible Developments' in K. Selvik and B.O. Utvik (eds) Oil States in the New Middle EastUprisings and Stability (Abingdon and New York: Routledge).

Luciani, G. and G. Salamé (eds.) (1988) The Politics of Arab Integration (London and New York: Croom Helm).

Farea al-Muslimi (2016) 'A History of Missed Opportunities: Yemen and the GCC', Carnegie Endowment for International Peace, http://carnegieendowment.org/ syriaincrisis/?fa=62405 (accessed on 5 February2016).

Noutary, E. and M. Tabet (2013) Emerging countries: the new Mediterranean FDI providers? 2012 report on MED Foreign Direct Investment attractiveness, ANIMA Investment Network, October, http://www.animaweb.org/sites/default/files/ain_fdipartnerships-2012_en_final.pdf (accessed on 8 April 2016).

Parra, M. D, I. Martinez-Zarzoso and C. Suárez-Burguet (2016) 'The impact of FTAs on MENA trade in agricultural and industrial products', Applied Economics, 48(25), DOI: 10.1080/00036846.2015.1119792.

Richards, A. and J. Waterbury (2007) A Political Economy of the Middle East, Second Edition (Boulder: Westview Press).

Snoj, J. (2013) 'Population of Qatar by nationality' (Doha: BQ Magazine) December, http://www.bqdoha.com/2013/12/population-qatar (accessed on 8 April 2016) and http://gulfmigration.eu/qatar-estimates-of-foreign-nationals-residing-in-qatar-bycountry-ofcitizenship-selected-countries-2014/ (accessed on 8 April 2016).

Snoj, J. (2015) 'UAE’s population by nationality' (Doha: BQ Magazine) April 12. http:// www.bq-magazine.com/economy/socioeconomics/2015/04/uae-population-bynationality (accessed on 8 April 2016)

United Nations (2013) International Migration Report 2013 (New York: Population Division of the Department of Economic and Social Affairs), ST/ESA/SER.A/346. 